\title{
Comparative analysis of mycobacterial infections in wild striped bass Morone saxatilis from Chesapeake Bay
}

\author{
Ilsa M. Kaattari*, Martha W. Rhodes, Howard Kator, Stephen L. Kaattari \\ Department of Environmental and Aquatic Animal Health, Virginia Institute of Marine Science, \\ College of William and Mary, Gloucester Point, Virginia 23062, USA
}

\begin{abstract}
During an ongoing epizootic of mycobacteriosis, wild striped bass Morone saxatilis from Chesapeake Bay were analyzed using 3 methods for detection of either mycobacterial infection or associated granulomatous pathology. The specific detection techniques, which utilized aseptically collected splenic tissue, were histology, quantitative culture and nested PCR. Based on analysis of 118 samples, detection of infection differed significantly between the 3 methods (chi-square, $p=$ 0.0007). Quantitative culture and nested PCR detected similar, higher rates of infection (69 and 75\%, respectively) than the histological method (52\%). Although primary PCR assays for a 924 to $940 \mathrm{bp}$ segment of the mycobacterial 16S rRNA gene were positive for genomic DNA from mycobacterial cultures, a secondary, nested PCR reaction for an internal 300 bp gene segment was required in order to detect mycobacteria within splenic tissue. A similar rate of mycobacterial infection was present in fish collected from all sites tested. Although all detection methods found that striped bass age 4.0 to $4.9 \mathrm{yr}$ had the highest positive incidence, nested PCR detected a higher frequency of mycobacterial infection in fish $\geq 6.0 \mathrm{yr}$ of age than the other 2 methods. Quantitative bacteriology was a more sensitive detection technique when the fish tissue contained $\leq 10^{3}$ mycobacteria $\mathrm{g}^{-1}$.
\end{abstract}

KEY WORDS: Mycobacteriosis · Striped bass · Chesapeake Bay

Resale or republication not permitted without written consent of the publisher

\section{INTRODUCTION}

Mycobacterium spp. infect over 160 species of saltwater and freshwater fishes (Chinabut 1999). Although more frequently described in fishes maintained in aquaria or aquaculture environments, mycobacteriosis also occurs in wild fishes. Specifically, mycobacterial infections have been reported in wild cod Gadus morhua, mountain whitefish Prosopium williamsoni, Northeast Atlantic mackerel Scomber scombrus, rabbitfish Siganus rivulatus, chinook salmon Oncorhynchus tshawytscha, striped bass Morone saxatilis, and yellow perch Perca flavescens (Abernethy \& Lund 1978, Sakanari et al. 1983, MacKenzie 1988, Daoust et al. 1989, Dalsgaard et al. 1992, Diamant et al. 2000). Recorded prevalences of mycobacteriosis in these fish range from 8 to $100 \%$.
Reports of mycobacteriosis in striped bass Morone saxatilis include aquacultured fish off the Pacific coast (Hedrick et al. 1987), experimentally infected fish (Wolf \& Smith 1999, Gauthier et al. 2003), and wild fish from the Pacific and Atlantic coasts, the latter specifically in the Chesapeake Bay (Landsdell et al. 1993, Heckert et al. 2001, Rhodes et al. 2001, 2003, 2004, 2005). Mycobacteriosis in Chesapeake Bay striped bass is noteworthy, as these fish constitute one of the region's most important recreational and commercial fisheries.

Confirmation of mycobacterial infection in fishes often relies solely on histological evidence, notably granuloma formation and/or presence of acid-fast bacteria. Although infection and disease are not synonymous, it is generally assumed that the presence and extent of granulomas correlates with the severity of 
mycobacterial disease. Culture of fish tissue for mycobacterial detection is often not attempted for a variety of reasons including the relatively slow growth of Mycobacterium spp. (Shotts \& Teska 1989, Rhodes et al. 2004). Harsh decontamination techniques, originally designed for mammalian mycobacteriosis, are generally employed in order to reduce the nonmycobacterial microbiota which can overgrow the mycobacteria (Majeed et al. 1981, Gomez et al. 1993, Chinabut 1999). However, decontamination methods can adversely affect mycobacterial viability and lead to an underestimation of mycobacterial infection intensity (Dailloux et al. 1999, Rhodes et al. 2004). Alternatively, determination of mycobacterial infection intensity can be accomplished by reliance on aseptic necropsy of internal tissues, followed by enumeration (Rhodes et al. 2004). Aseptic necropsy also reduces chances of detecting extraneous, environmentally derived mycobacteria in fish tissues when using molecular techniques such as PCR. A variety of PCR assays have been utilized for specific and rapid detection of piscine mycobacteria (Knibb et al. 1993, Talaat et al. 1997, Bruno et al. 1998, Kotlowski et al. 2004).

In this study, these 3 mycobacterial detection methods (histology, quantitative culture and nested PCR) are compared in assessing aseptically collected splenic tissue from wild striped bass in the Chesapeake Bay.

\section{MATERIALS AND METHODS}

Fish collection and initial processing. Wild striped bass Morone saxatilis ( $\mathrm{N}=$ 118) were collected either by hook and line (primarily at striped bass fishing tournaments) or by haul seine net surveys from June 1999 through December 2001. Sites of fish collection ranged from near the southern mouth of the Chesapeake Bay (Virginia Beach, Virginia) to the Potomac River. In addition, fish were collected by the same methods from several mid-tolower Chesapeake Bay embayments and tributaries comprising the Great Wicomico River, the Piankatank River, the Rappahannock River, the York River and the Potomac River, and from locations near Reedville and Deltaville, Virginia (Fig. 1). Each fish was assigned a unique, sequen- tial identification number and the total length and presence of gross, external pathology was recorded. Fish were stored on ice until aseptic necropsy was performed, generally within $8 \mathrm{~h}$ of receipt. Necropsies were conducted in a laminar flow hood (Nuaire, Type II Class 2A/B3, Plymouth, Minnesota), using Biosafety Level 2 conditions, as described by the Centers for Disease Control and Prevention and National Institutes of Health (1999). Aseptically collected splenic tissue (approx. 0.5 to $1.0 \mathrm{~g}$ ) from each fish was subdivided $(0.1$ to $0.5 \mathrm{~g}$ ) for homogenate preparation and for histological examination as described below.

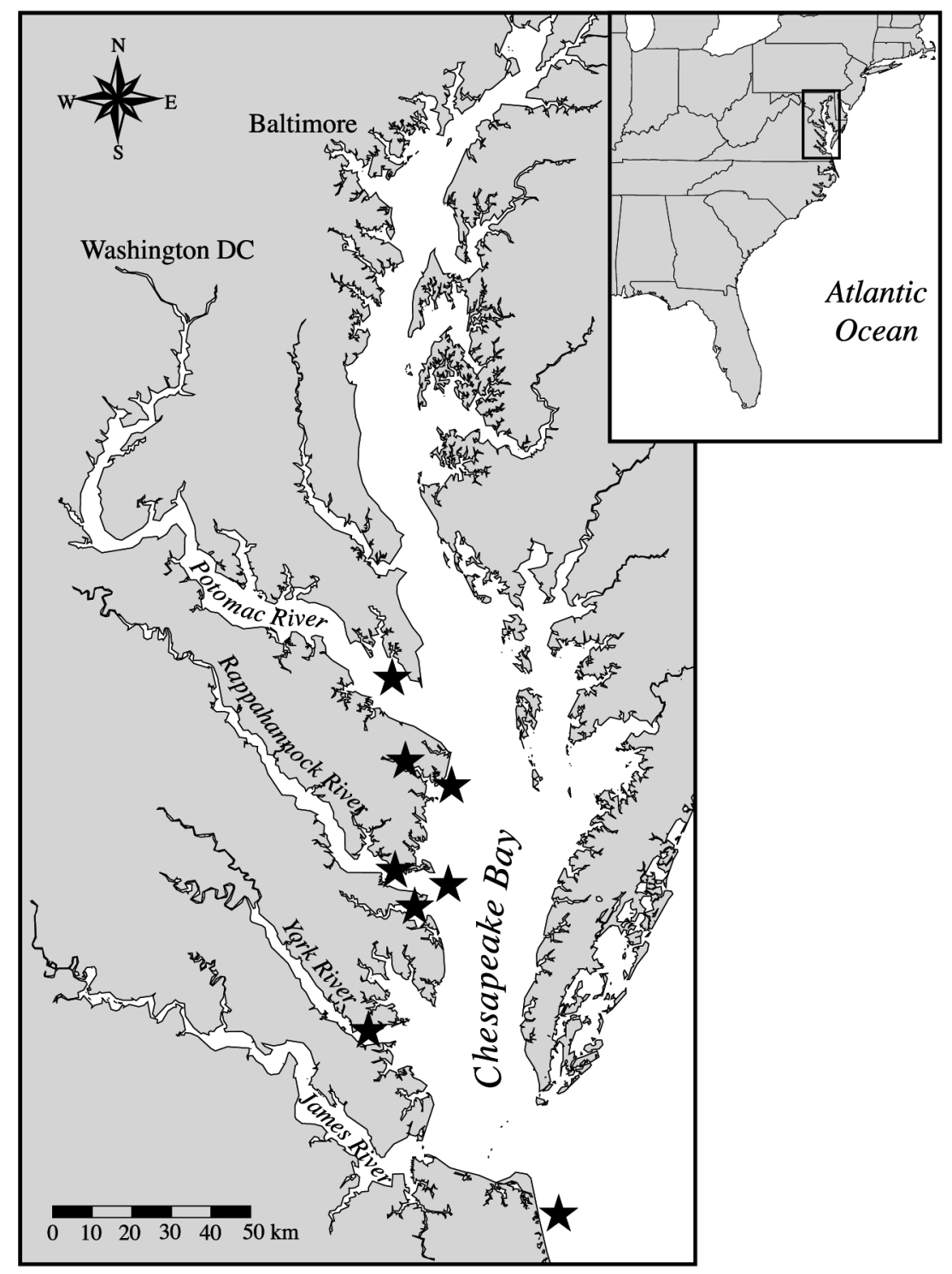

Fig. 1. Collection sites (starred) in the Chesapeake Bay for wild striped bass Morone saxatilis. The most southern, starred location is Virginia Beach, and in ascending order, the starred sites are the York River, Piankatank River, Deltaville, Rappahannock River, Great Wicomico River, Reedville, and Potomac River 
Histology. For histological evaluation, splenic tissue was fixed in $10 \%$ buffered formalin for $48 \mathrm{~h}$, and then processed using standard procedures (Prophet et al. 1994). A minimum of 9 randomly selected $5 \mu \mathrm{m} \mathrm{sec-}$ tions of Harris' hematoxylin and eosin (H\&E) stained splenic tissue for each fish was examined at $40 \times$ for the presence and number of granulomatous lesions.

Quantitative bacteriology. A weighed splenic tissue subsample was homogenized in $2 \mathrm{ml}$ Butterfield buffer (Anonymous 1995), using a Ten broeck tissue grinder, and 2 equal portions of this homogenate were transferred to sterile $1.5 \mathrm{ml}$ microcentrifuge tubes. One tube was frozen at $-20^{\circ} \mathrm{C}$ for molecular analysis (nested $\mathrm{PCR}$ ) and the second was processed for enumeration of mycobacteria by immediate serial dilution and spreadplating onto duplicate plates of Middlebrook 7H10 agar with albumin-dextrose-catalase (ADC) or oleic acid-albumin-dextrose-catalase (OADC) enrichment, which produced a mildly selective medium (MDA). The original homogenate was also spread-plated onto brain heart infusion (BHI) agar, a non-selective medium, to monitor for heterophilic bacterial contamination and the presence of pathogens other than mycobacteria.

Plates were incubated at $23^{\circ} \mathrm{C}$ for $3 \mathrm{mo}$. This incubation temperature was utilized as Rhodes et al. (2004) had previously determined that temperatures above $23^{\circ} \mathrm{C}$ were not conducive to growth of all mycobacterial species recovered from striped bass. Culture plates were stored in plastic bags to prevent desiccation of the media during incubation.

All morphologically distinct colonies were examined for acid-fastness (Ziehl Neelsen stain) and acid-fast colonies were streaked onto MDA to obtain purified cultures. Purified isolates have been characterized and described in a separate study (Rhodes et al. 2004).

Mycobacterial densities were expressed as colony forming units (CFU) $\mathrm{g}^{-1}$ tissue. Means and standard deviations of these densities were calculated from logtransformed data.

Aseptic collection and processing of splenic tissue were successful in that only 1 spleen sample $(\mathrm{N}=$ 1/119) had a high density of contaminant, heterotrophic bacteria. This sample was omitted from further data analysis.

Nested PCR of Mycobacterium spp. Nested PCR was performed on DNA prepared from frozen aliquots of splenic homogenates. Approximately $500 \mu \mathrm{l}$ of the thawed homogenate were spun briefly and the tissue pellet was rinsed in sterile water. DNA was then extracted from the tissue pellet using the method of Reischl et al. (1994) with an additional, final $10 \mathrm{~min}$ boiling step to ensure nonviability of the mycobacteria (Buck et al. 1992). DNA was purified using a standard method (Ausubel et al. 1992): phenol/chloroform/ isoamyl alcohol (P/C/IAA at 25:24:1 ratio) extraction, followed by ethanol precipitation and subsequent rinsing of the DNA pellet with $75 \%$ ethanol. DNA was then resuspended in TE $(10 \mathrm{mM}$ Tris- $\mathrm{HCl}, \mathrm{pH}$ 8.0, $1 \mathrm{mM}$ EDTA), its concentration was measured using a spectrophotometer (DynaQuant, Hoefer, San Francisco, California) and it was stored at $-20^{\circ} \mathrm{C}$ until used for PCR assays. Positive controls included DNA derived from pure bacterial cultures extracted according to Reischl et al. (1994). Cultures, which included reference strains of Mycobacterium spp. (M. chelonae, $M$. flavescens, $M$. fortuitum, $M$. gordonae, $M$. kansasii, M. marinum, M. scrofulaceum, M. simiae, and M. terrae) and Escherichia coli, were obtained from the Environmental Protection Agency, Cincinnati, Ohio, and from the Consolidated Laboratory Services, Commonwealth of Virginia, Richmond, Virginia. Additionally, DNA was also extracted from mycobacteria previously isolated from wild striped bass, including 2 new species, M. shottsii and M. pseudoshottsii nov. (Rhodes et al. 2001, 2003, 2004, 2005). DNA from Nocardia otitidiscaviarum (ATCC 14629) was also used as a negative control.

The first phase of the nested PCR reactions employed previously described primers, forward (T39) and reverse (T13), for a 924 to $940 \mathrm{bp}$ segment of the Mycobacterium spp. 16S rRNA gene (Talaat et al. 1997). PCR amplifications were conducted in a $100 \mu \mathrm{l}$ reaction mixture containing $200 \mu \mathrm{M}$ (each) of dATP, dCTP, dGTP, and dTTP, $1 \times$ reaction buffer (RB) (100 mM Tris-HCl, pH 8.3, $0.5 \mathrm{M} \mathrm{KCl}_{i} 15 \mathrm{mM} \mathrm{MgCl}_{2}$, $0.01 \%$ gelatin), 10 to $100 \mathrm{ng}$ of DNA template extracted from bacterial cultures or 500 to $1000 \mathrm{ng}$ of DNA extracted splenic tissue of striped bass, $0.6 \mu \mathrm{M}$ of each primer, and $2.5 \mathrm{U}$ of Taq polymerase. All PCR reagents were obtained from Sigma-Aldrich, St. Louis, Missouri. Amplification was performed in an MJ Research PTC 200 thermocycler (MJ Research) with the following program: 1 cycle of $95^{\circ} \mathrm{C}$ for $5 \mathrm{~min}$, followed by 30 cycles of denaturation at $94^{\circ} \mathrm{C}$ for $1 \mathrm{~min}$, annealing at $53^{\circ} \mathrm{C}$ for $1 \mathrm{~min}$, and extension at $72^{\circ} \mathrm{C}$ for $1 \mathrm{~min}$, followed by a final extension at $72^{\circ} \mathrm{C}$ for $10 \mathrm{~min}$. We analyzed $20 \mu \mathrm{l}$ of the amplified PCR products by electrophoresis on a $1.0 \%$ agarose gel, and visualized them using ethidium bromide. Positive (Mycobacterium spp. DNA template) and negative (no template DNA) controls were included in each set of reactions. For the secondary phase of the nested PCR assay, 1 to $3 \mu \mathrm{l}$ of the primary $100 \mu \mathrm{l}$ reaction mixture was employed as a source of template DNA, together with the internal primers (T531 and PRET 43) designed by Talaat et al. (1997). These primers amplified a conserved 300 bp Mycobacterium spp. sequence within the larger, originally amplified 924 to 940 bp PCR amplicon. The same type reagents and cycle program 
as described for the primary assays were used in the secondary phase of nested PCR. We analyzed $20 \mu \mathrm{l}$ of the amplified nested PCR products by electrophoresis on a $1.0 \%$ agarose gel, and visualized them using ethidium bromide. Immediately following the initial experiments and at several subsequent times, PCR or nested PCR products were cloned and sequenced to verify that mycobacterial 16S RNA gene segments were being amplified (data not shown).

'Spiking' experiments were conducted to assess the sensitivity of the nested PCR method by adding known quantities of mycobacterial DNA genomic equivalents derived from pure cultures to negative samples of fish splenic tissue. Then extraction and purification of genomic DNA was conducted as usual before performing nested PCR assays. These experiments demonstrated that the minimal threshold for positive detection of mycobacteria was approximately $10^{3}$ mycobacteria $\mathrm{g}^{-1}$ splenic tissue (data not shown).

Fish age determination and statistical analysis. Age of fish was estimated using data provided by the Anadromous Fishes Research Program (VIMS), correlating total length of fish to age based on fish scale assessment. Regression analysis of length on age was performed using simple linear regression and the regression ANOVA table. Statistical tests were performed using Statview Version 5.0.1 (SAS Institute).

\section{RESULTS AND DISCUSSION}

Overall, $52 \%$ of all samples ( $N=61$ of 118 ) were histologically-positive for granulomas, $69 \%$ ( $\mathrm{N}=81$ of 118) were culture-positive for mycobacteria, and $75 \%$ ( $\mathrm{N}=88$ of 118) were PCR-positive for mycobacteria. Comparison of the 3 methods for all sampled fish showed a significant difference in overall detection of mycobacterial infection (chi-square, $\mathrm{p}=0.0007$ ).
Table 1. Morone saxatilis infected with Mycobacterium spp. Categories of mycobacterial infection based on histological assessment of splenic tissue of 118 wild striped bass compared to quantitative culture means. Degree of infection is based on number of granulomas in observed splenic tissue, where $0=$ negative, 1 to $10=$ light, 11 to $100=$ moderate, $>100=$ heavy; culture mean is mean $( \pm 1 \mathrm{SD}) \log \mathrm{CFU} \mathrm{g}{ }^{-1}$ for fish in each category

\begin{tabular}{|lrc|}
\hline Degree of infection & $\begin{array}{c}\text { No. infected } \\
\text { fish (\%) }\end{array}$ & Culture mean \\
\hline Negative & $57(48.3)$ & $2.2 \pm 1.4$ \\
Light & $38(32.2)$ & $3.6 \pm 1.5$ \\
Moderate & $19(16.1)$ & $5.0 \pm 1.4$ \\
Heavy & $4(3.4)$ & $6.1 \pm 1.0$ \\
\hline
\end{tabular}

Table 1 summarizes the intensity of mycobacterial infections based on histological assessment of splenic tissue and on quantitative culture. Degrees of pathology ranged from negative (no detectable granulomas) to a qualitative description as highly infected $(>100$ detectable granulomas). Often granulomas in the fish were large enough to be macroscopically visualized during necropsy (Fig. 2).

Fig. 3A shows typical results for initial PCR assays with either mycobacterial cultures or splenic tissues. Fig. 3B demonstrates that nested PCR assays with the same samples as for Fig. 3A amplify a 300 bp product and are required for detection of mycobacterial infection in fish tissues.

All 3 methods were in agreement for $56.8 \%$ of the fish samples, i.e. either all positive or all negative (Table 2). In instances where the bacterial culture was positive but both histology and PCR were negative, the majority ( 8 of $12,66.7 \%$ ) of samples had mycobacterial densities $\leq 10^{3} \mathrm{CFU} \mathrm{g}^{-1}$.

Table 3 presents a 2-way comparison of viable cell densities, i.e. low $\left(10^{1}\right.$ to $\left.10^{3} \mathrm{CFU} \mathrm{g}^{-1}\right)$ and high

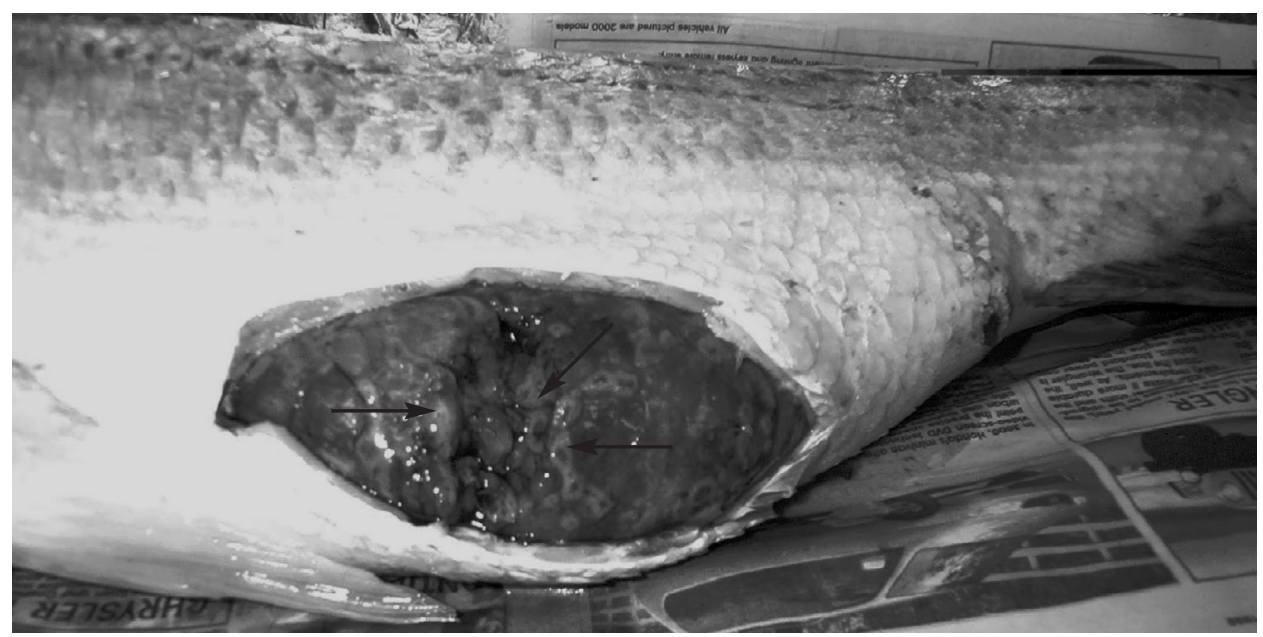

Fig. 2. Morone saxatilis infected with Mycobacterium spp. Fish No. MR122, collected at a fishing tournament in Deltaville, Virginia; weight $6010 \mathrm{~g}$, total length $835 \mathrm{~mm}$. Age based on regression analysis was 8.8 yr. Although this fish had a healthy-appearing exterior, aseptic necropsy revealed pronounced granulomatous splenomegaly filling the entire body cavity; arrows highlight several granulomas. M. shottsii was ultimately cultured from spleen at density of $150000 \mathrm{CFU} \mathrm{g}^{-1}$; both histological and molecular methods were also positive 
Table 2. Morone saxatilis infected with Mycobacterium spp. Results of 3-way comparison of mycobacterial detection methods. Histo: Histology (granulomas); Bact: quantitative bacterial culture; PCR: PCR/nested PCR. Values represent incidence in categorical number/total number (relative percentage)

\begin{tabular}{|c|c|c|c|c|c|c|c|}
\hline Histo & + & Histo & + & Histo & + & Histo & + \\
\hline Bact & + & Bact & + & Bact & 0 & Bact & 0 \\
\hline PCR & + & PCR & 0 & PCR & \pm & PCR & 0 \\
\hline $53 / 118$ & $(44.9 \%)$ & $3 / 118$ & $(2.5 \%)$ & $4 / 118$ & $(3.4 \%)$ & $1 / 118$ & $(0.8 \%)$ \\
\hline Histo & 0 & Histo & 0 & Histo & 0 & Histo & 0 \\
\hline Bact & + & Bact & 0 & Bact & + & Bact & 0 \\
\hline PCR & + & PCR & + & PCR & 0 & PCR & 0 \\
\hline $13 / 118$ & $(11 \%)$ & 18/118 & $\overline{(15.3 \%)}$ & $12 / 118$ & $\overline{(10.2 \%)}$ & $14 / 118$ & $\overline{(11.9 \%)}$ \\
\hline
\end{tabular}

net were generally younger than those caught and kept by hook and line during fishing tournaments. There was a significant difference between the 3 detection techniques regardless of collection method, i.e. hook and line (chi-square, $\mathrm{p}=$ 0.0007), or haul seine net (chi-square, $\mathrm{p}=$ 0.0448). In contrast to histological analysis and culture-based methods, infection rates for nested PCR were similar for both collection groups of fish regardless of capture method and associated age differences.

The prevalence of splenic mycobacteriosis based on the various age categories of fish and the positive percentage for each

$\left(>10^{3} \mathrm{CFU} \mathrm{g}^{-1}\right.$ ) cell densities, compared to the presence or absence of infection determined by histological or PCR methods. Frequency of agreement between the methods includes the sum of both methods being either negative or positive, and ranged from 67 to $75 \%$.

Table 4 shows the percentage of fish positive for mycobacterial infection for each of the 3 detection methods compared to the location of fish collection. This analysis revealed an exception to the overall similarity between culture and PCR methods for detecting infection. At 2 of the striped bass fishing tournaments, (Colonial Beach, Virginia and Deltaville, Virginia) the nested PCR method detected a higher prevalence of mycobacterial infection.

To examine this difference, an analysis was conducted that compared the age of fish to the method of fish collection (Table 5). Fish caught by haul seine

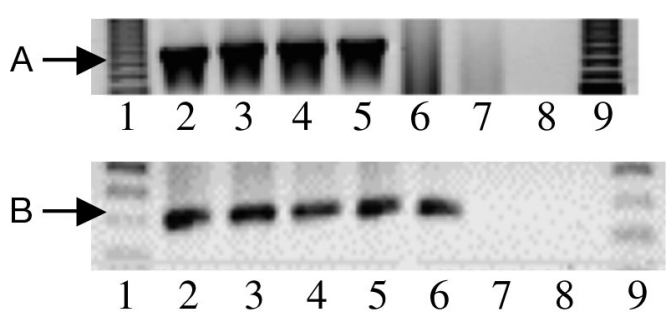

Fig. 3. Morone saxatilis infected with Mycobacterium spp. (A) PCR reactions visualized on $1 \%$ agarose gel, stained by ethidium bromide; Talaat et al. (1977)-designed primers were used with genomic DNA extracted from 2 cultures of reference mycobacteria, 2 cultures of Mycobacterium spp. from striped bass, mycobacterially infected or non-infected splenic tissue from striped bass, or negative (no DNA template) control. (B) Nested PCR reactions visualized on $1 \%$ agarose gel, stained by ethidium bromide, for same samples as in (A). Lanes 1 \& 9: Molecular weight marker (100 bp ladder); 2: $M$. fortuitum (reference strain); 3: $M$. gordonae (reference strain); 4: M. pseudoshottsii (from splenic tissue); 5: M. shottsii (from splenic tissue); 6: mycobacterially infected splenic tissue (detected by all 3 methods); 7: mycobacterially non-infected splenic tissue (detected by all 3 methods); 8: negative control (no template DNA) method of detection is shown in Fig. 4. Fish that were 4.0 to $4.9 \mathrm{yr}$ of age had the highest incidence of mycobacterial infection by all 3 detection methods. In this age category, $74 \%$ of striped bass were positive by histology, $95 \%$ were positive by quantitative bacteriology and $86 \%$ were positive for nested PCR.

Although histological methods are commonly employed for the detection of mycobacterial infection in fishes (Sakanari et al. 1983, Bruno et al. 1998, Cardinal 2001, Rhodes et al. 2001, 2004, Gauthier et al. 2003), concurrent use of culture- and molecular-based detection methods remain limited. In this comparative study, the histological method of observing granulomas in aseptically collected splenic tissue revealed fewer mycobacterial infections than did quantitative bacteriology or nested PCR. This finding, along with previous reports which have described difficulties detecting acid-fast bacilli in granulomatous fish tissues (Gomez et

Table 3. Morone saxatilis infected with Mycobacterium spp. Results of 2-way comparison of mycobacterial detection methods, with subcategories of quantitative bacteriology data. Agreement in each comparison equals sums of percentage of negative or positive detection by both methods

\begin{tabular}{|c|c|c|}
\hline & $\begin{array}{c}\text { Negative } \\
(\%)\end{array}$ & $\begin{array}{c}\text { Positive } \\
(\%)\end{array}$ \\
\hline \multicolumn{3}{|l|}{ Bacteriology: Histology } \\
\hline Negative (no growth) & 28 & 4 \\
\hline Low $+\left(10^{1}-10^{3}\right.$ CFU g $\left.^{-1}\right)$ & 12 & 8 \\
\hline High $+\left(>10^{3} \mathrm{CFU} \mathrm{g}^{-1}\right)$ & 9 & 39 \\
\hline Agreement: $75 \%$, Disagre & $5 \%$ & \\
\hline \multicolumn{3}{|c|}{ Bacteriology: PCR/Nested PCR } \\
\hline Negative (no growth) & 12 & 19 \\
\hline Low $+\left(10^{1}-10^{3}\right.$ CFU g $\left.^{-1}\right)$ & 7 & 11 \\
\hline High $+\left(>10^{3} \mathrm{CFU} \mathrm{g}^{-1}\right)$ & 7 & 44 \\
\hline Agreement: $67 \%$, Disagre & $3 \%$ & \\
\hline \multicolumn{3}{|l|}{ PCR/Nested PCR: Histology } \\
\hline Negative & 22 & 3 \\
\hline Positive & 27 & 48 \\
\hline \multicolumn{3}{|c|}{ Agreement: $70 \%$, Disagreement: $30 \%$} \\
\hline
\end{tabular}


Table 4. Morone saxatilis infected with Mycobacterium spp. Mycobacterial prevalence as a function of location of fish collection

\begin{tabular}{|lrrrr|}
\hline Location & $\begin{array}{c}\text { No. } \\
\text { fish }\end{array}$ & $\begin{array}{r}\text { \% with mycobacterial infection } \\
\text { Histology Bacteriology Nested PCR }\end{array}$ \\
\hline Mid Bay & & & & \\
Colonial Beach fishing tournament & 7 & 43 & 43 & 71 \\
Great Wicomico River & 1 & 0 & 0 & 0 \\
Reedville coast & 1 & 100 & 100 & 100 \\
Reedville fishing tournament & 15 & 53 & 67 & 73 \\
Mid Bay total & 24 & 50 & 58 & 71 \\
Lower Bay & & & & \\
Deltaville fishing tournament & 21 & 33 & 43 & 86 \\
Lynnhaven fishing tournament & 6 & 33 & 83 & 83 \\
Piankatank River & 1 & 100 & 100 & 100 \\
Virginia Beach coast & 1 & 100 & 100 & 100 \\
York River & 65 & 58 & 78 & 71 \\
Lower Bay total & 94 & 52 & 71 & 76 \\
Total & 118 & 52 & 69 & 75 \\
\hline
\end{tabular}

Table 5. Morone saxatilis infected with Mycobacterium spp. Mycobacterial prevalence as a function of method of fish collection. Age in years

\begin{tabular}{|lccccc|}
\hline Capture source & \multirow{2}{*}{$\begin{array}{c}\text { No. } \\
\text { fish }\end{array}$} & Mean & \multicolumn{2}{c|}{ No. positive/total no. detected by: } \\
& age & Histology & Bacteriology & Nested PCR \\
\hline Hook and line & 53 & $7.4 \pm 3.1$ & $23 / 53=43 \%$ & $30 / 53=57 \%$ & $42 / 53=79 \%$ \\
Haul seine net & 65 & $4.0 \pm 1.1$ & $38 / 65=58 \%$ & $51 / 65=78 \%$ & $46 / 65=71 \%$ \\
\hline
\end{tabular}

of the host. On the other hand, reliance on granuloma detection as evidence for mycobacteriosis can also lead to false positive results since granulomas can be caused by microorganisms other than mycobacteria (Gomez et al. 1993, Falkinham 2002). In this instance, however, there are numerous reports of typical granulomatous development due to mycobacteria in wild striped bass from the Chesapeake Bay (Heckert et al. 2001, Rhodes et al. 2001, 2004, Gauthier et al. 2003).

Histological examination can be completed relatively quickly, requiring only 3 to $4 \mathrm{~d}$ from collection of fish tissue to potential diagnosis, and can also assess the severity of disease. We suspect that a similar development in initial appearance and density of mycobacterial granulomas is occurring in the wild striped bass from the Chesapeake Bay as described for wild mackerel (MacKenzie 1988). Our research demonstrated a general correlation between increasing numbers of detectable splenic granulomas and mycobacterial al. 1993, Colorni et al. 1998, Gauthier et al. 2003), indicates that strict reliance upon histological approaches could result in false negatives. The possibility exists that splenic granulomas may be absent from early infections due to an insufficient hypersensitive response

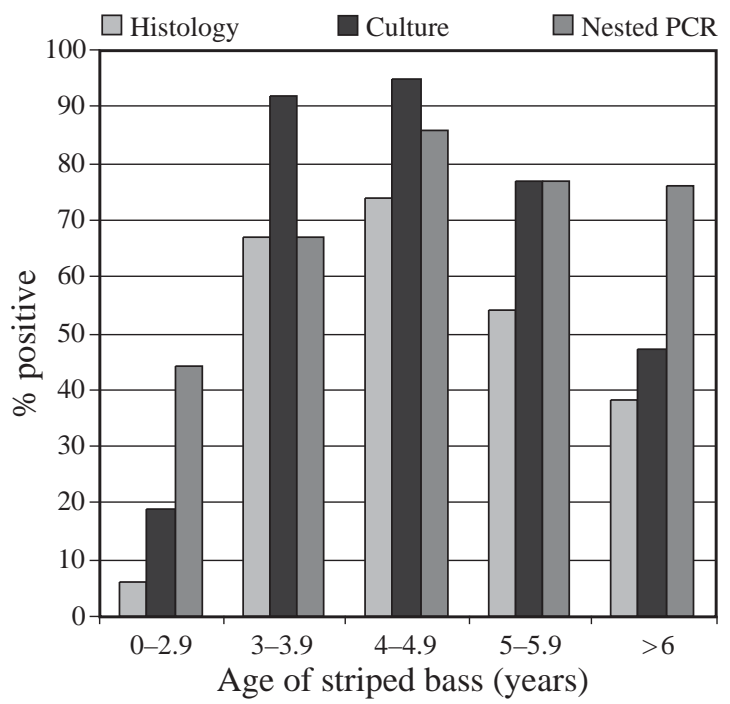

Fig. 4. Morone saxatilis infected with Mycobacterium spp. Percentage of splenic samples positive for mycobacterial infection as a function of age category detected by histology, culture, or nested PCR. Sample size: 0 to $2.9 \mathrm{yr}, \mathrm{n}=16 ; 3$ to $3.9 \mathrm{yr}, \mathrm{n}=12 ; 4$ to $4.9 \mathrm{yr}, \mathrm{n}=43 ; 5$ to $5.9, \mathrm{n}=13 ; \geq 6 \mathrm{yr}, \mathrm{n}=34$ densities of CFU g ${ }^{-1}$ fish tissue. Specifically, when splenic tissues of striped bass have detectable granulomas, these fish have, minimally, 20-fold higher mycobacterial densities than do fish without granulomas. Overall, $52 \%$ of all samples in this study ( $N=61$ of 118) exhibited granulomas by histology. This rate is very similar to the overall $48 \%$ positive rate found in a previous, larger study ( $\mathrm{N}=1899$ ) of wild striped bass (Cardinal 2001), which relied predominantly on histology to detect mycobacteriosis.

Culturing mycobacteria from splenic tissue not only provided data on the overall incidence of mycobacteriosis, but also cell concentrations which presumably reflect the intensity of mycobacterial infection. Overall, $69 \%$ of the samples ( $N=81$ of 118 ) were culture positive for mycobacteria, and mycobacterial densities in nearly $75 \%$ of culture-positive fish were $>10^{3}$ mycobacterial CFU g ${ }^{-1}$ splenic tissue.

The data in Fig. 4 demonstrate that both histological and culture-based methods may underestimate the incidence of mycobacterial infection in wild striped bass compared to the detection frequency by nested PCR, notably for the older striped bass ( $\geq 6 \mathrm{yr}$ ). This finding may reflect partial or complete resolution of the active mycobacterial infection. Mycobacteria in such fish may have been rendered nonviable, physiologically compromised and/or sequestered within granulomas, and thus might not be recoverable by culture. 
The remaining mycobacterial DNA in such culturally and/or histologically-negative fish might still be present in sufficient quantity/quality, however, to allow detection by nested PCR. Another potential cause of underestimation by quantitative culture could be the inadvertent absence in media of an essential growth factor or growth condition (e.g. temperature, Rhodes et al. 2004) that would be required for growth of each Mycobacterium spp. present in the samples examined. The sensitivity for detection of mycobacteria by culture in this study was $10 \mathrm{CFU} \mathrm{g}{ }^{-1}$. The use of a larger spleen sample could have increased the sensitivity of this method. Unfortunately, the 2 to 3 mo period required for the primary isolation of some striped bass mycobacteria (Rhodes et al. 2004) is an unalterable detriment to rapid diagnoses. In contrast, nested PCR techniques show promise for rapid detection of mycobacteria. The specific PCR protocol utilized in this study reliably amplified a genus-specific 924 to $940 \mathrm{bp}$ segment of the 16S rRNA gene from pure mycobacterial cultures. Thus far, cultures of 14 different Mycobacterium spp. (reference strains or fish isolates) have yielded positive PCR results with the genus-specific primers (data not shown). The 924 to $940 \mathrm{bp}$ gene segment includes a well-known hypervariable section of the 16S rRNA gene (Kirschner et al. 1993, Tortoli et al. 1996, Turenne et al. 2001, Tortoli 2003) flanked by conserved ends. When sequenced, this large segment of DNA aids in speciation of Mycobacterium spp. However, in contrast to the original report by Talaat et al. (1997) for $M$. marinum or $M$. fortuitum-infected fish (fish species not identified), we were unable to detect the 924 to $940 \mathrm{bp}$ PCR product when directly assaying splenic tissue of wild striped bass. To detect the mycobacterial infection in such tissues, nested PCR assays had to be utilized. The nested PCR assay amplified an internal, $300 \mathrm{bp}$ segment of the larger gene segment (Fig. 3). The sequence of this small segment, when compared to others in GenBank, was useful in confirming both the type of gene and the genus Mycobacterium, but was insufficient for speciation. One may speculate that the nested PCR assay was required for detection of mycobacteria in splenic tissues of striped bass because the original 924 to 940 bp product was too low in concentration to be detected, and/or tissue inhibitors (Chakravorty \& Tyagi 2001) in the primary PCR reaction prevented detection.

To detect potential false positives with the molecular assays, negative controls (no template DNA) were routinely employed in each set of PCR or nested PCR reactions. Another type of negative control used occasionally was DNA from the splenic tissue of striped bass that had already been proven to be negative for mycobacterial infection by all 3 methods of detection. Insufficient quality and/or quantity of genomic DNA template could certainly cause false negatives for mycobacterially-infected fish tissues. According to Burkardt (2000), another method to detect, or rule out, such false negative assays would be to employ an internal control in the PCR assays.

The present study indicated that wild striped bass can become infected with mycobacteria at $<3 \mathrm{yr}$ and can continue to survive to minimally 6 yr of age. Fish from Virginian waters of the Chesapeake Bay possessed similar rates of infection, with overall $75 \%$ of sampled fish having detectable mycobacteria. The source and route of infection is unknown. Whether there is any risk to humans in contact with such mycobacterially-infected striped bass remains to be studied.

Acknowledgements. We thank P. Blake, J. Cardinal, and D. Zwerner for their histological analyses, D. Booth for her assistance in bacteriology, and E. Burge, D. Gauthier and C. Hager for their help with fish collection. This work was supported by the Virginia Marine Resource Commission and the Virginia Institute of Marine Science (Contribution No. 2669 of the Virginia Institute of Marine Science).

\section{LITERATURE CITED}

Abernethy CS, Lund LE (1978) Mycobacteriosis in mountain whitefish (Prosopium williamsoni) from the Yakima River, Washington. J Wildl Dis 14:333-336

Anonymous (1995) Bacteriological analytical manual, 8th edn. US Food and Drug Administration. AOAC International, Gaithersburg, MD

Ausubel FM, Brent R, Kingston RE, Moore DD, Seidman JG, Smith JA, Struhl K (eds) (1992) Short protocols in molecular biology, 2nd edn. John Wiley \& Sons, New York

Bruno DW, Griffiths J, Mitchell CG, Wood BP, Fletcher ZJ, Drobniewski FA, Hastings TS (1998) Pathology attributed to Mycobacterium chelonae infection among farmed and laboratory-infected Atlantic salmon Salmo salar. Dis Aquat Org 33:101-109

Buck GE, O'Hara LC, Summersgill JT (1992) Rapid, simple method for treating clinical specimens containing Mycobacterium tuberculosis to remove DNA for polymerase chain reaction. J Clin Microbiol 30:1331-1334

Burkardt H (2000) Standardization and quality control of PCR analyses. Clin Chem Lab Med 38:87-91

Cardinal JL (2001) Mycobacteriosis in striped bass, Morone saxatilis, from Virginia waters of Chesapeake Bay. MS thesis, Virginia Institute of Marine Science, College of William and Mary, Gloucester Point, VA

Centers for Disease Control and Prevention and National Institutes of Health (1999) Biosafety in microbiological and biomedical laboratories, 4th edn. US Government Printing Office, Washington, DC

Chakravorty S, Tyagi JS (2001) Use of guanidinium isothiocyanate in the isolation of Mycobacterium tuberculosis DNA from clinical material. FEMS Microbiol Lett 205: 113-117

Chinabut S (1999) Mycobacteriosis and nocardiosis. In: Woo PTK, Bruno DW (eds) Fish diseases and disorders, Vol 3. Viral, bacterial, and fungal infections. CAB International, Wallington, p 319-340

Colorni A, Avtalion R, Knibb W, Berger E, Colorni B, Timan B 
(1998) Histopathology of sea bass (Dicentrarchus labrax) experimentally infected with streptomycin and garlic (Allium sativum) extract. Aquaculture 160:1-17

Dailloux M, Laurain C, Weber M, Hartemann PH (1999) Water and nontuberculous mycobacteria. Water Res 33: 2219-2228

Dalsgaard I, Mellergaard S, Larsen JL (1992) Mycobacteriosis in cod (Gadus morhua L.) in Danish coastal waters. Aquaculture 107:211-219

Daoust PY, Larson BE, Johnson GR (1989) Mycobacteriosis in yellow perch (Perca flavescens) from 2 lakes in Alberta. J Wildl Dis 25:31-37

Diamant A, Banet A, Ucko M, Colorni A, Knibb W, Kvitt H (2000) Mycobacteriosis in wild rabbitfish Siganus rivulatus associated with cage farming in the Gulf of Eilat, Red Sea. Dis Aquat Org 39:211-219

Falkinham JO III (2002) Nontuberculous mycobacteria in the environment. Clin Chest Med 23:529-551

Gauthier DT, Rhodes MW, Vogelbein WK, Kator H, Ottinger CA (2003) Experimental mycobacteriosis in striped bass Morone saxatilis. Dis Aquat Org 54:105-117

Gomez S, Bernabe A, Gomez MA, Navarro, JA, Sanchez AJ (1993) Fish mycobacteriosis: morphopathological and immunocytochemical aspects. J Fish Dis 16:137-141

Heckert RA, Elankumaran S, Milani A, Baya A (2001) Detection of a new Mycobacterium species in wild striped bass in the Chesapeake Bay. J Clin Microbiol 39:710-715

Hedrick RP, McDowell T, Groff J (1987) Mycobacteriosis in cultured striped bass from California. J Wildl Dis 23: 391-395

Kirschner P, Springer B, Vogel U, Meier A, Wrede A, Kiekenbeck M, Bange FC, Bottger EC (1993) Genotypic identification of mycobacteria by nucleic acid sequence determination: report of a 2-year experience in a clinical laboratory. J Clin Microbiol 31:2882-2889

Knibb W, Colorni A, Ankaoua M, Lindell D, Diamant A, Gordin H (1993) Detection and identification of a pathogenic marine Mycobacterium from the European seabass Dicentrarchus labrax using the 16S rDNA sequences. Mol Mar Biol Biotechnol 2:225-232

Kotlowski R, Martin A, Ablordey A, Chemlal K, Fonteye PA, Portaels F (2004) One-tube cell lysis and DNA extraction procedure for PCR-based detection of Mycobacterium ulcerans in aquatic insects, molluscs and fish. J Med Microbiol 53:927-933

Landsdell WD, Dixon B, Smith N, Benjamin L (1993) Isolation of several Mycobacterium species from fish. J Aquat Anim Health 5:73-76

MacKenzie K (1988) Presumptive mycobacteriosis in Northeast Atlantic mackerel, Scomber scombrus. J Fish Biol 32: 263-275

Majeed SK, Gopinath C, Jolly DW (1981) Pathology of spontaneous tuberculosis and pseudotuberculosis in fish. J Fish

Editorial responsibility: David Bruno,

Aberdeen, UK
Dis 4:507-512

Prophet EB, Mills B, Arrington JB, Sobin LH (eds) (1994) Laboratory methods in histotechnology. Armed Forces Institute of Pathology, American Registry of Pathology, Washington, DC

Reischl R, Pulz M, Ehret W, Wolf H (1994) PCR-based detection of mycobacteria in sputum samples using a simple and reliable DNA extraction protocol. Biotechniques 17: 844-845

Rhodes M, Kator H, Kotob S, van Berkum P and 7 others (2001) A unique Mycobacterium sp. isolated from an epizootic of striped bass (Morone saxatilis). Emerg Infect Dis 7:896-899

Rhodes MW, Kator H, Kotob S, van Berkum Pand 6 others (2003) Mycobacterium shottsii sp. nov., a slowly growing species isolated from Chesapeake Bay striped bass (Morone saxatilis). Int J Syst Evol Microbiol 53:421-424

Rhodes MW, Kator H, Kaattari I, Gauthier D, Vogelbein W, Ottinger CA (2004) Isolation and characterization of Mycobacterium spp. from striped bass, Morone saxatilis, from the Chesapeake Bay. Dis Aquat Org 61:41-51

Rhodes MW, Kator H, McNabb A, Deshayes C and 11 others (2005) Mycobacterium pseudoshottsii sp. nov., a slowly growing chromogenic species isolated from Chesapeake Bay striped bass (Morone saxatilis). Int J Syst Evol Microbiol 55:1139-1147

Sakanari J, Reilly CA, Moser M (1983) Tubercular lesions in Pacific coast populations of striped bass. Trans Am Fish Soc 112:565-566

Shotts EB, Teska JD (1989) Bacterial pathogens of aquatic vertebrates. In: Austin B, Austin A (eds) Methods for the microbiological examination of fish and shellfish. Ellis Horwood, Chichester, p 164-186

Talaat A, Reimschuessel R, Trucksis M (1997) Identification of mycobacteria infecting fish to the species level using polymerase chain reaction and restriction enzyme analysis. Vet Microbiol 58:229-237

Tortoli EB (2003) Impact of genotypic studies on mycobacterial taxonomy: the new mycobacteria of the 1990s. Clin Microbiol Rev 16:319-354

Tortoli EB, Bozzetta E, Burrini C, Lacchini C, Mantella A, Penati V, Simonetti MT, Ghittino C (1996) Identification of the newly described Mycobacterium poriferae from tuberculous lesions of snakehead fish (Channa striatus). Comp Immunol Microbiol Infect Dis 19:25-29

Turenne CY, Tschetter L, Wolfe J, Kabani A (2001) Necessity of quality-controlled 16S rRNA gene sequence databases: identifying nontuberculous Mycobacterium species. J Clin Microbiol 39:3637-3648

Wolf JC, Smith SA (1999) Comparative severity of experimentally induced mycobacteriosis in striped bass Morone saxatilis and hybrid tilapia Oreochromis spp. Dis Aquat Org 38:191-200

Submitted: November 26, 2004; Accepted: April 15, 2005

Proofs received from author(s): October 11, 2005 